\title{
Disclaimer:
}

This is an electronic version of an article published in Business History, and can be found online at: http://www.tandfonline.com/doi/abs/10.1080/00076791.2011.618223

\section{Corporate Political Activity in Less Developed Countries: the Volta River Project in Ghana, 1958-1966 ${ }^{1}$}

\author{
Stephanie Decker, Aston Business School \\ S.decker@aston.ac.uk
}

\begin{abstract}
The article expands existing categorisation of political and economic governance by including literature on less developed countries (LDCs). In four consecutive negotiations between the US multinational Kaisers and the US and Ghana government in the early 1960s, it is shown that the company reached levels of influence that are at odds with existing explanations. In order to understand corporate political activities in LDCs, analysis needs to go beyond static factors (political risk) and include dynamic factors such as diplomatic relations and 'arenas of power', and consider the role of the investor's home country relative to the host economy.
\end{abstract}

Keywords: Corporate Political Activities, Volta River Project, Kwame Nkrumah, Kaiser Aluminum \& Chemicals Company, Ghana

The nature and extent of corporate political power is a controversial issue particularly in less developed countries. Often the size of major international companies is compared with that of African countries - which, due to its faulty methodology, does not really address the question adequately (Dicken, 2007, pp. 232-233). The significant political power differential between developed and less developed countries suggests that the political power held by the home economy translates directly into economic power for its multinational companies (MNCs), i.e. an extension of the "gunboat diplomacy" argument. Yet there are also surprising cases of corporate impotence, for example in the recent Chad-Cameroon Oil Pipeline Project (Gould \& Winters, 2007). MNCs like to highlight their vulnerability relative to the power of sovereign countries on such

${ }^{1}$ [Acknowledgments go here.] 
occasions, in effect seeing business influence as directly proportional to the degree goodwill and acceptance of the host economy.

Both arguments in effect embed business power either in the conditions of the home or the host economy. This means that foreign companies from developed economies as a group should have been either highly effective in influencing policy in states that displayed significant economic nationalism, or have very little power as a group. Economic nationalism, in this case defined as hostility to foreign investment, was common in less developed countries (LDCs) in the 1960s and 1970s. Ghana under Kwame Nkrumah (1957-1966) was a wellknown case at the time because of the political importance that the USA attributed to the first sub-Saharan colony that achieved independence. And while Nkrumah was suspicious of corporate influence, both domestic and foreign, but required foreign assistance for his ambitious development plans, there was a grudging acceptance of foreign investment if foreign influence could be contained (Esseks, 1971; T. Jones, 1976, p. 162; Killick, 1978, pp. 37-38).

Nevertheless, the nature of corporate political power in Nkrumah's Ghana does not easily fit either scenario of corporate power or impotence. The majority of foreign firms at the time were British, with some relatively recent US American, French and West German investment. Their influence on policy was modest, and declined in this time period. This seems to confirm the argument that host country attitudes towards foreign investment is more significant than home country power. There was one notable exception to this, which was the US firm Kaiser Industries and its subsidiary, Kaiser Aluminum \& Chemicals Company (KACC), which had enormous influence on policy in Ghana, especially in the time period from 1959 to 1963: "Kaisers is more influential in Ghana than the US government," 2 one observer remarked. This cannot easily be attributed to the greater power of the USA relative to European states, because US relations to Ghana were strained at the time. Moreover, in 1962, another US investor, the flour manufacturer Pillsbury, quickly found that the government of Ghana reneged on its assurances. ${ }^{3}$

This leaves historians with the conclusion that Kaisers' influence in Ghana was contingent on its strategic position in US-Ghanaian investment plans, and the extremely close and cordial relationship that existed between Ghana's head of state and Kaisers' president Edgar Kaiser, and vice-president Chad Calhoun (as described in Moxon, 1969, 1984). But this explanation is equally unsatisfactory, because although the relationship remained cordial, Kaisers' influence declined noticeably after 1963. The obsolescing bargain model (Penrose, 1959; Vernon, 1973) has explained this in terms of the erosion of bargaining power of foreign companies once their investment was sunk. However, in 1963 Kaisers' investment had been agreed but was not "sunk" (construction did not begin until 1965) and the terms of their bargain never obsolesced either.

2 TP Heffelfinger II. to William Marks, 6.11.61, BANC MSS 87/35c, Ctn. 42, fl. 5.

${ }^{3}$ Chad F Calhoun, "Ghana March 1962", n.d., Bancroft Library Berkeley [hereafter BANC] MSS 87/35c [Eugene Trefethen papers] Ctn. 42, fl. 8; Business

International, 19.4.63, pp. 4-5. 
What I propose is a different explanation, in which the power of individual multinationals is dependent, to some extent, on their capabilities for corporate political activities, but more importantly on the nature of the relationship between host and home economies. Similar arguments have been advanced for North American investment in Central America (Bucheli, 2008, 2010; Haber, Maurer, \& Razo, 2003) Individual MNCs become unusually powerful in a very visible way not for accidental reasons, but because they can take the role of an intermediary channel of corporate diplomacy. Forbes Magazine went so far as to describe Edgar Kaiser as "the only link between the US and Ghanaian governments" in 1961, due to his skills in dealing with "prickly foreigners" (cited from Forbes in Graham, 1982, pp. 238-239, FN 67). In a situation where diplomatic relations between host and home country are tense, yet some rapprochement, especially by the home country of the investor, is still being sought, companies that capture a position as corporate politicians can become unusually powerful.

Existing theories of have focused on categorising either corporate political strategies or host country economic strategies. However the role played by the home country government has not been sufficiently connected with host economy conditions. Kaisers managed a complex web of political networks that stretched from Washington to Accra and that involved negotiating the cognitive distortion of the Cold War era. The political strategies employed have to be seen in their international political and economic context. Thus Kaiser's political influence in Washington, together with the unstable political environment in Ghana, opened up political opportunities. Also significant was the industry context: The aluminium industry was globally oligopolistic and renowned for its close relationship to national governments, especially in the US, the UK and France, because of its strategic relevance (Hove, forthcoming; Perchard, 2008, 2010).

This article seeks to contribute to the literature by integrating the business history and political science of Africa with work on corporate political activities (CPA) from international business and strategy (see also Bucheli, 2008). The emergent field of African business history, which has recently been reviewed in Business History Review (Tignor, 2007), has traditionally been under-researched compared to Latin American or Asian enterprise - note the absence of a chapter in Business History around the World (2003). Nevertheless, there has been a diverse range of publications on the subject in the last few years (Austin \& Uche, 2007; Decker, 2010; Mager, 2008; Maltby \& Tsamenyi, 2010; Piquet, 2004 ; Verhoef, 2008). As Antony Hopkins argued recently (Hopkins, 2010), the key issue for Africa is still poverty, and economic history should reflect this concern. Hence business history should address questions such as in how far companies contributed to development, and how much influence they wielded in their relationship to government. The contribution to the literature on CPA is twofold. By integrating research on Africa, I extended some existing matrices of political economy systems to better represent conditions in LDCs (Table 1). Secondly, I propose to combine the policies of home countries with those of the host country in order to establish a dynamic model of corporate political activities (Figure 1). 


\section{Researching corporate political strategies}

How influential was Kaisers during the Nkrumah years? How does business in general influence policy in Africa? There has hardly been any work on the nature of corporate political activity in Africa, other than Rodney (1972), Rood (1976), and Widstrand (1975). Much of the literature either employs an explicitly Marxist analysis, or tends to deal quite descriptively with the legal and administrative factors relevant to the expropriation drives of the 1970s. Moreover, they frequently address the issue of the states' economic activity rather than the private sector's political activity (see for example Wilson, 1990). There is little clear conceptualisation of corporate influence on the political processes, in contrast to the dependency literature in Latin America. Yet even dependency authors focus more on governments' economic policies that seek to curb the influence of foreign direct investment (Gereffi \& Evans, 1981) than on the detailed corporate strategies geared towards gaining political influence.

In contrast, corporate political activity has received a lot of interest in business studies since the 1990s, especially from a strategic management perspective. This reflects the rising importance of emerging economies in international business, where political activity is relatively more important to business success than competitive market position (Peng, 2003). Hillman \& Hitt (1999) proposed a three stage model that differentiates strategic choices of corporate political activity (CPA), which provides a useful framework:

1. Two general approaches: transactional or relational

2. Two levels of participation: individual or collective

3. Three types of generic political strategies: information, financial incentive, and constituency building

A firm's decision-making could be determined either by its internal corporate preference, or by responding to its local environment. In a multi-level study of institutional duality of multinationals in present-day Western Europe, Hillman and Wan (2005) found greater support for local responsiveness than corporate preference. Therefore it is necessary to relate strategic choices to the political economy within which they take place.

Murtha and Lenway (1994) conceptualised the state as a strategic actor. They argue that the credibility of its policies is inversely related to its target specificity (i.e. whether government can control individual economic transactions or just sets broad industry or national conditions). This means the more power and opportunity a state has to determine the outcome of specific economic transactions, the lower its credibility will be, because political negotiations would trump general market rationality, making the outcome less predictable. As a result, the authors develop a matrix of political regimes, which combines transactional governance (market vs. central planning) with the nature of property rights (public vs. private). While the notion of a planned command economy (central planning with public ownership) is relevant for Eastern European transition economies, it is not helpful to understand the conditions in less developed economies. Therefore I suggest a different categorisation, which focuses on the differences in the political system, which is only imperfectly correlated to public ownership of resources (see Table 1). 
Table 1: Corporate legitimacy and political systems

\begin{tabular}{|c|c|c|c|c|}
\hline \multirow[b]{2}{*}{$\begin{array}{l}\text { Transactional } \\
\text { governance }\end{array}$} & \multicolumn{4}{|c|}{ Political system } \\
\hline & & $\begin{array}{c}\text { Patronage } \\
\text { relational, insecure property rights) }\end{array}$ & & $\begin{array}{c}\text { Pluralistic } \\
\text { (rule-based, secure property rights) }\end{array}$ \\
\hline Coordination & - & $\begin{array}{l}\text { Government involvement in } \\
\text { economic organisation } \\
\text { Influence through personal } \\
\text { connections } \\
\text { - Most LDCs } \\
\text { - Ghana under Nkrumah }\end{array}$ & - & $\begin{array}{l}\text { Government involvement in economic } \\
\text { organisation } \\
\text { Influence constrained by impersonal } \\
\text { decentralisation of power } \\
\text { - Coordinated market economies }\end{array}$ \\
\hline Market & $\begin{array}{l}- \\
-\end{array}$ & $\begin{array}{l}\text { Government avoids interference in } \\
\text { economy beyond basic policies } \\
\text { Influence through personal } \\
\text { connections } \\
\text { - Transition \& emerging } \\
\quad \text { economies }\end{array}$ & - & $\begin{array}{l}\text { Government avoids interference in } \\
\text { economy beyond basic policies } \\
\text { Influence constrained by impersonal } \\
\text { decentralisation of power } \\
\text { - Liberal market economies } \\
\text { - US (although at mid-century } \\
\quad \text { some economic coordination) }\end{array}$ \\
\hline
\end{tabular}

Note: Developed on the basis of Murtha \& Lenway (1994), Guillen (2000), Peng (2003), Soskice \& Hall (2001).

The most significant difference between developed and many developing countries is that social and political relations in African states are based on patronage networks (Bayart, 1993; Chabal \& Daloz, 1999), and this opens avenues for negotiation and influence on a personal level. Unsurprisingly, companies respond by opting for an individual, relational approach to political relations that may be coupled with an information or a financial strategy option. This is supported by findings from Bates (1981) for Africa, who highlighted the existence of "coalitions between sectors of society, including industry and government", and Evans' (1979) argument of a triple alliance in Brazil between government and domestic and foreign business.

However, in the case of Kaiser, their political strategy choices are the same in the US, which may reflect a strong corporate preference, as it is difficult to argue that the political environment was similar to Ghana. Why are Kaisers' political strategy choices fundamentally similar in Ghana and US when the political economy context was so markedly different? At mid-century, the USA showed a more coordinated pattern in its economic governance than Table 1 suggests. Yet it is Kaisers' privileged position in both Washington and Accra at a time when the relationship between Ghana and the US was strained that seems to have elevated the firm to the status of a "corporate diplomat", who mediated between different mindsets.

Some concepts from political science and economics are helpful in understanding the case of Kaisers in the US and Ghana. The visibility problem highlights that large firms may be wary of exerting too much influence too openly in order to avoid a backlash in public opinion, and also creates pressures to make credible claims and commitments. However, Bernhagen and Braeuniger (2005) show that companies are sometimes able to use visibility to their advantage. They argue that the crucial factor here is information asymmetry: if policy makers lack information and consider the risk of adverse effects too high, they will accept business demands. Kaisers' position as mediator meant that the company had superior information that both governments were keen to access. 
In a contemporary piece on the US political economy, Lowi (1964, pp. 690-713) highlighted that the pattern of political influences differed between so-called "arenas of power", of which he identified three: distributive, regulatory, and redistributive. Distributive policies here refer to political patronage in the broadest sense, where political decisions can be disaggregated and dispensed in small and isolated units, irrespective of a general rule, where the beneficiaries and the losers never need to come into direct confrontation. This type of policy is a typical feature of less developed states, as well as resource policies, and thus highly relevant for this case. In the regulatory arena, general rules that favour one group over another are created, and can only be disaggregated to a sectoral level, not to that of an individual firm. Redistributive policies determine the relationship between social classes, such as taxation or welfare programmes, and are determined strongly by ideological positions. Of these three arenas, the first and last are most relevant to the present case: in the distributive arena, firms were most likely to act individually and achieve high degrees of influence on isolated issues, while their influence in the redistributive arena, i.e. taxation, tended to be more limited and based on collective action.

None of the authors mentioned above were considering this in an international context of diplomacy and foreign direct investment. Much of the existing literature in international business has focused on the host country conditions, especially the level of political risk. Yet Haber, Maurer \& Razo (2003) have argued for the case of US investment in Mexico that changes in formal political institutions had no effect corporate investment decisions as long as firms had diplomatic leverage to counteract them. Bucheli (2009) shows that home country conditions significantly affect corporate political activities in the case of Canadian investment in Colombia. Both studies highlight dynamic factors that are broadly absent in the more static models of international business and political science.

\section{Figure 1: Home and host countries' dynamic and static conditions affecting the degree of corporate influence}

What the model in figure 1 predicts is that static factors, such as high levels of political risk or corporate visibility do not in themselves predict the level of 
corporate influence or security of property rights. Haber, Maurer \& Razo (2003) make a similar argument from a neo-institutional perspective, distinguishing between formal and informal institutions. Here I distinguish between static and dynamic factors, which operate at host as well as at home country level. I argue that it is the dynamic factors that can turn high visibility and political risk into an advantage, as was the case for Kaisers in the first three instances (III.1, III.2, III.3), but also into a disadvantage, as the final case (III.4) shows. This does not remove agency, as Kaisers' keen awareness of the shifting political tides led to distinct departure in their political activities in 1964, which became more defensive and geared towards reducing visibility. The subsequent narrative will demonstrate how significant international diplomacy and a shift from a distributive to a redistributive political arena are in understanding the case of Kaisers in Ghana.

\section{Contextual factors: The United States in Ghana in the 1950s and 1960s}

\section{II.1 Kaisers in the US}

The Kaisers group of companies were frequently described as 'government entrepreneurs' (Adams, 1997) which to the activities of the founder, Henry J Kaiser. A famous businessman in the US, his meteoric rise on the American corporate scene really began with his company's collaboration in the consortium that built the Hoover dam. Subsequently his firms were involved in one way or another in the major New Deal dam building projects (Mayo, Enson, \& Chen, 2008). This rapid expansion was made possible by close contacts to government officials in Washington, showing a corporate preference for an individualrelational approach to CPA.

The effectiveness of Kaisers' political strategy raises the question whether the classification of the US as a pluralistic market economy according to Table1 is entirely accurate. In the 1950s and 1960s, business power was clearly relevant in certain 'arenas' and foreign direct investment decisions that were linked to government backing such as the VRP was part of the distributive arena, in which individual companies could gain significant influence on isolated issues (Lowi, 1964).

Kaiser's political involvement in Ghana, and almost to the same extent in the US, can be categorised as relational and individual, with a generic information strategy. There is no evidence of financial incentives, either legal or illegal, beyond the normal hosting of business partners, and only rudimentary attempts at constituency building within a narrow range of professionals directly related to the project. Kaiser's choices in Ghana are neither surprising nor fundamentally different from the rest of the business community (for an example see Moxon, 1969, 1984, p. 269), but suggest that the USA at mid-century may need to be treated as a more coordinated market economy.

\section{Figure 2: Edgar E Kaiser}




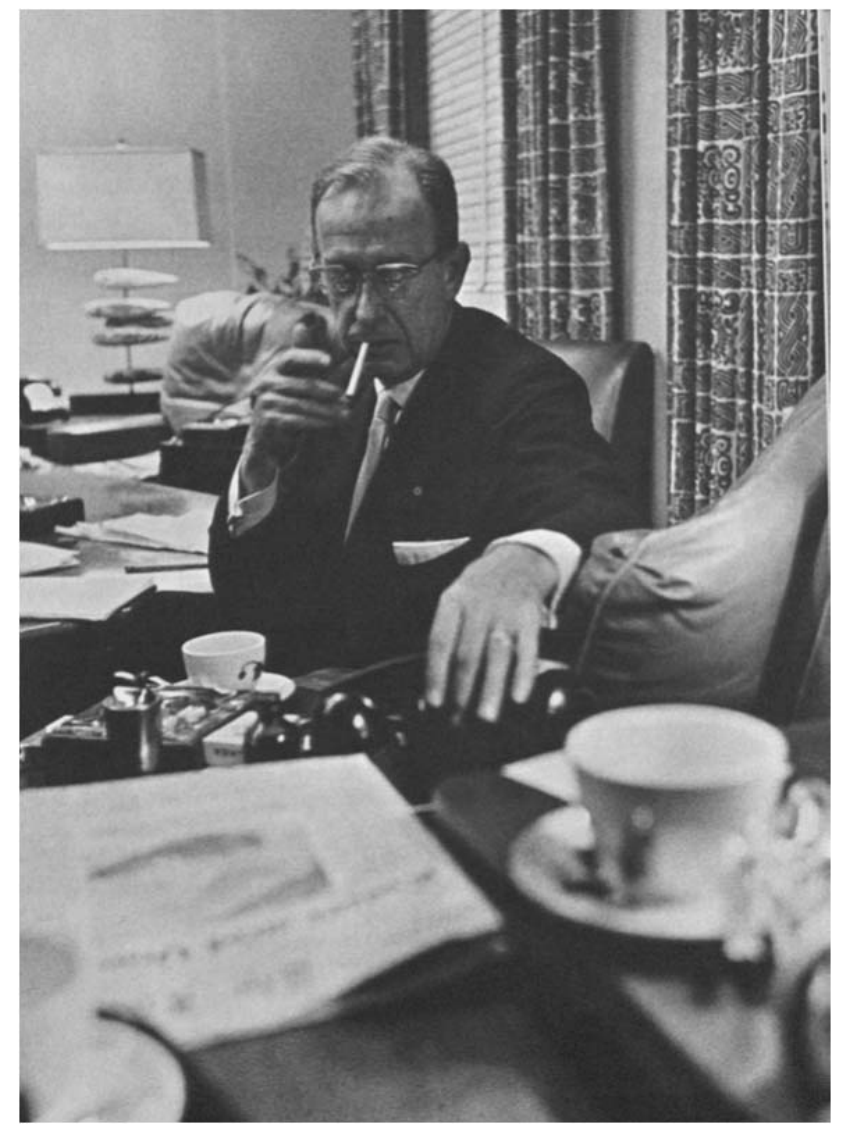

Source: (Kaiser Corporation, 1968, p. 63)

Yet Kaisers' success in the VRP was as much due to the company's strategy to internationalise. Henry Kaiser's son Edgar F Kaiser (Figure 2) became involved early in the rapidly expanding conglomerate. When Henry Kaiser retired in 1959, Edgar took over. He focused on taking the Kaiser companies abroad, especially Kaiser Engineers (KE) and Kaisers Aluminium and Chemicals Company (KACC), the latter the largest of the Kaiser companies by sales, assets and employees (Hart, 1980, p. 48).

Figure 3: Edgar Kaiser and his successor Cornell Maier with the Development Award, 1974 


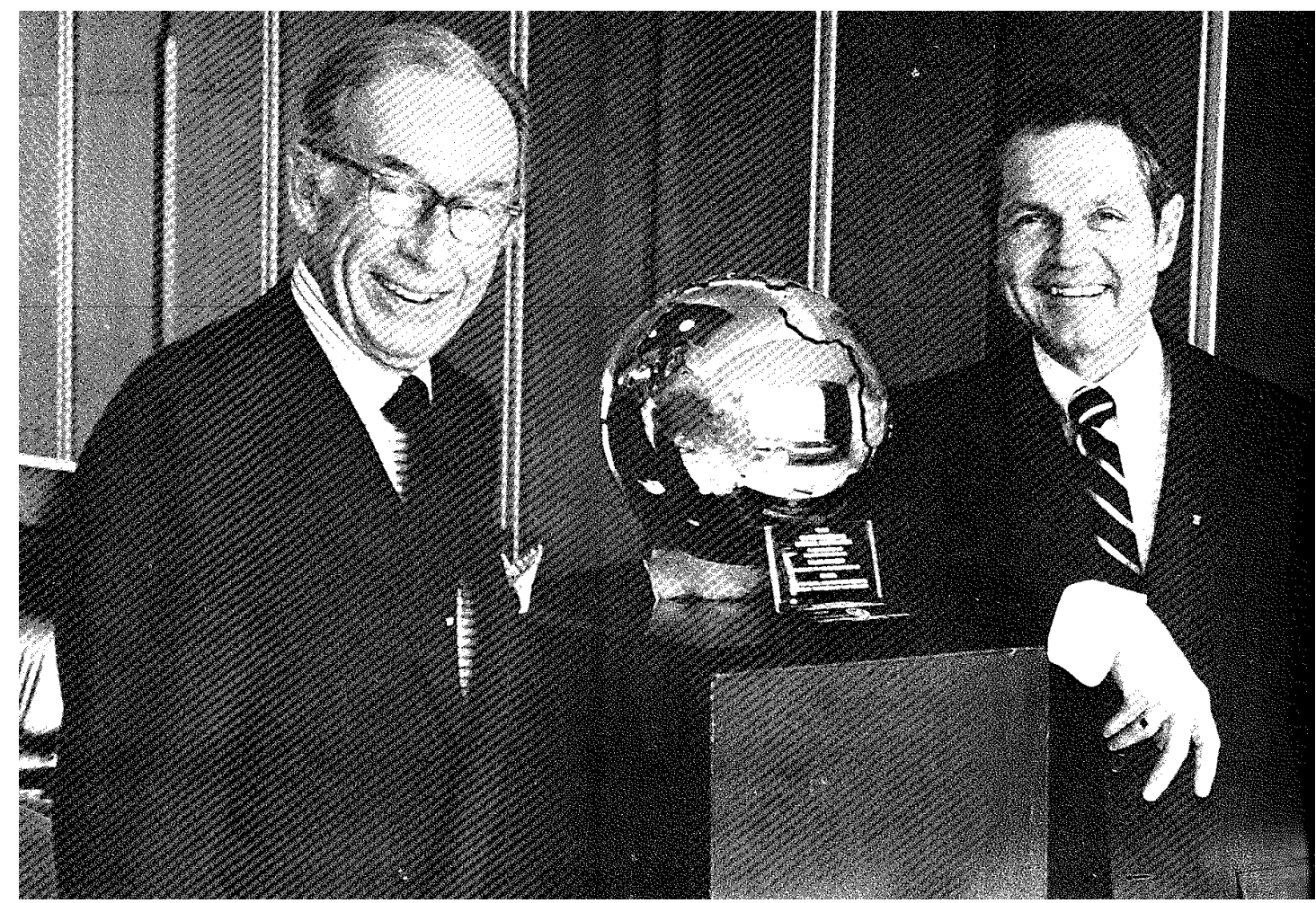

Source: (Stein, 1980, p. 184)

Kaisers' involvement in the VRP raised their visibility internationally. In 1974 they received the first Development Award from the Overseas Private Development Corporation (Figure 2) for their "contribution to the social and economic development of Ghana, and the success of Valco" (Stein, 1980, p. 185). Nkrumah's friendship with Edgar Kaisers, and especially with the company's Vice President, Chad Calhoun, seemed to be sincere, as well as his admiration for the company founder, Henry J Kaiser. Calhoun even likened the two: "So much he [Nkrumah] is like H.J. [Kaiser] - always with vision - thinking ahead." The older Kaiser would have been less enthusiastic about this statement, as he considered the Ghanaian president a communist. ${ }^{4}$ Without doubt Kaisers gained significant strategic advantages from their highly personalised, relational approach to political contacts domestically and internationally, at a time when diplomatic links were rather tenuous, but both governments sought a rapprochement.

\section{II.2 The US policy towards Ghana and decolonizing Africa}

The US government involvement in the VRP has to be viewed both in terms of their concern for communist influence in the newly decolonized states in Africa and Asia (Connelly, 2000). Highly visible, large-scale development projects served a distinct function in this context, as the US

${ }^{4}$ Calhoun to Kaiser, 21.2.63, Ctn. 42, fl. 10; "Notes of meeting at Accra, Ghana, 4-5 Oct 1961 of Edgar Kaiser, Chad Calhoun with Nkrumah", Ctn. 42, fl. 4; Calhoun "A report, comments and observations of Trip to Ghana Sept 18-23, 1962", BANC MSS 87/35c , Ctn 42, fl. 9. Edgar to Henry J. Kaiser, 28.12.61, BANC MSS 83/42c [Henry J Kaiser papers], Ctn. 173, fl. 1. 
perceived the TVA as a successful model and potential "weapon" against communism (Smith, 2006, p. 250).

In 1961 Fortune magazine compared the VRP to the TVA:

"In the religion of the new nationalism, a dam is the grandest temple, promising miracles in industrial development and richer living. The TVA, probably more than any other American material achievement, has impressed and tantalized the emerging nations of Asia and Africa, stirring hopes of constructing similar monumental projects on their own rivers." (Siekman, 1961)

The successes and failures of the TVA featured prominently in the thinking of the US administration during the negotiation of the VRP (Moxon, 1969, 1984, p. 110). This "embodiment of progress" (Hart, 1980), built by construction companies like Kaiser Engineers, became epitomes of the post-war export of a New Deal-influenced vision of modernisation which was employed as a Cold War weapon (Smith, 2006, p. 19).

As Connelly (2000) argued, the Eisenhower administration was far more concerned with avoiding a potential North-South conflict with the emerging nations than has hitherto been assumed, and the initiation of the revised VRP is a good example of this. The Eisenhower administration approached Kaisers to help breathe new life into the VRP, which had been shelved by the UK and the aluminium companies (Noer, 1984, pp. 62-63; The Economist, 1956). The failure of the West with regard to the Aswan dam, which was built with the help of the Soviet Union, weighed heavily in the decision of policymakers not to let Ghana "go communist" (Noer, 1984, p. 64).

The VRP represented the Western, capitalist model of progress that was based on free enterprise. ${ }^{5}$ Private enterprise was also instrumental in maintaining US government's commitment at critical points in the VRP negotiations, when their irritation at Nkrumah's increasingly pro-Soviet rhetoric intensified. The State Department was becoming highly critical by 1961, and requested from Edgar Kaiser and Chad Calhoun confirmation of reports from the US embassy that Nkrumah had become "slovenly and dirty in dress and habits, etc.". The businessmen roundly rejected this: "If anything, we noted that he was more neatly and nattily dressed - - well-tailored clothes. Everything about him reflected just the opposite of the reports." 6

Kaisers' role became increasingly that of a 'corporate diplomat' in the time period from 1959 to 1963 as a result of the incompatible international policies of the US and Ghana. This can only be understood in the context of the assessment by the Eisenhower and Kennedy administrations that Ghana, as the first subSaharan African country to become independent, formed an important part of

\footnotetext{
5 "Power for an Emerging Nation", Newsfront: Management's News Magazine, February 1967, BANC MSS 85/61c [Edgar F. Kaiser papers], Ctn. 200, folder 12. 6 "Notes of meeting at Accra, Ghana, 4-5 Oct 1961 of Edgar Kaiser, Chad Calhoun with Nkrumah", BANC MSS 87/35c, Ctn. 42, fl. 4.
} 
their future Africa policy. Thus diplomatic rapprochement was sought in the time period from 1957 to 1964.

While in 1961 there were still voices in the US press commenting that "the Nkrumahs and Nassers are moderates in the African context", by 1964 criticism of Nkrumah had reached a fever pitch in response to anti-American riots and demonstrations (see Figure 4). ${ }^{7}$ Lyndon B Johnson's administration pursued a more antagonistic Cold War policy than Kennedy or Eisenhower, who were more concerned with anti-imperial North-South issues (Connelly, 2000).

Figure 4: US press representation of Kwame Nkrumah, 1964

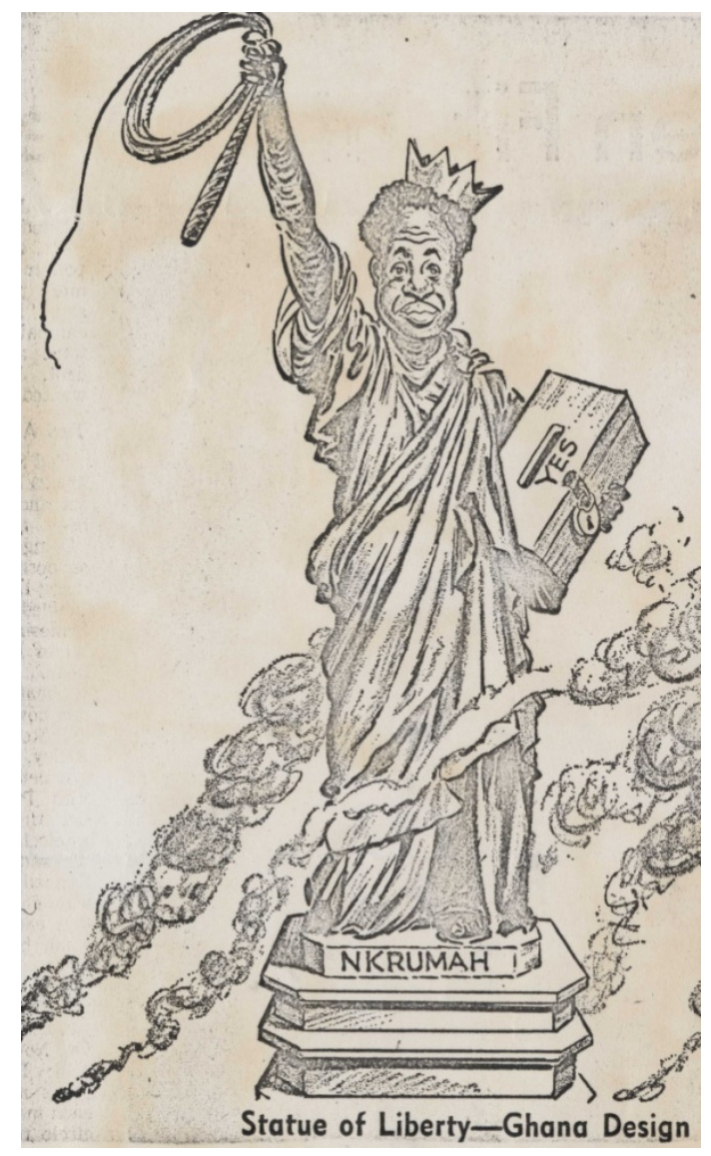

Source: "Statue of liberty, Ghana Design", Sunday Star, Washington DC, 9.2.64, BANC MSS 85/61c, Ctn. 320, fl. 6b.

\section{II.3 Financing the VRP}

The VRP had its roots in a colonial vision, when Sir A E Kitson, chief of a geological survey of the Gold Coast, suggested a hydroelectric development for the production of aluminium from local bauxite in $1915 .^{8}$ In the late 1940 , the British government became interested due to wartime constraints in aluminium

\footnotetext{
${ }^{7}$ New Republic, 13.3.61, BANC MSS 83/42c, Ctn. 173, fl. 3.

8 'Volta River Hydroelectric Project', n.d. [pres. 1961-1963], BANC MSS 85/61c, Ctn. 200, folder 16.
} 
and commissioned William Halcrow and Partners to study the feasibility of the project. Kwame Nkrumah placed his support behind the idea in 1952 when he was released from prison to head the first African government. The VRP - the dam and the aluminium smelter - formed the basis of a grand view of industrial development in Ghana, fuelled by domestic bauxite and cheap power. In the 1950 s and 1960s large-scale integrated industrial projects seemed to promise the way out of the vicious cycle of underdevelopment. In Ghana, the VRP became the embodiment of a vision of modernity spearheaded by the country's first president, Kwame Nkrumah (Westad, 2005, pp. 90-91).

Yet the original design of the VRP was bigger than the combined capacity of the UK and Ghana to fund, thus in 1956 the UK Preparatory Commission approached the World Bank to obtain finance. Eventually the Colonial Office (CO) shelved the plan due to a global surplus of aluminium and high interest rates (The Economist, 1956), and the notion to involve private investment from the UK was abandoned as well (Perchard, 2010). Nkrumah approached the US government in 1957 after UK and Canadian firms had declined. The US government contacted Kaisers (Noer, 1984). Kaisers initially sought to form a consortium with other aluminium companies, which mostly backed out and left Kaiser with ninety percent of the investment and its management, and Reynolds Aluminium with a ten percent minority stake. Kaiser also provided a reassessment of the original plans, which indefinitely postponed the realisation of a fully integrated aluminium industry by importing alumina rather than developing the processing of local bauxite (Graham, 1982, pp. 176, 179). This significantly limited the economic contribution of the scheme for Ghana's development (Hart, 1980, pp. 103-112). However, while usually attributed to Kaisers, the British government had apparently already given up on the idea of an integrated aluminium industry in 1956 in favour of a "smelter only" solution, so Kaisers' reassessment seems to have only reflected an emerging consensus (Hove, forthcoming, p. 18)

Financing of the VRP was reliant on the confirmed use of hydroelectric power by an aluminium smelter to be built by Kaisers. The US and UK governments, and the World Bank, were only willing to provide long-term loans under this condition (see Figure 5). In the 1950s and 1960s, the absence of an extensive electrical grid in Ghana meant that general power consumption in the first few years would be low.

The sums involved were immense at the time, and the eventual form of the VRP was already a trimmed down version of the original plans. Building the hydroelectric dam cost $\$ 196 \mathrm{~m}$, which today would have been $\$ 1.1 \mathrm{bn}$ in terms of cost. ${ }^{9}$ Foreign loans covered half the construction costs, Ghana paid the other $\$ 98 \mathrm{~m}$ from its sizeable Sterling reserves. Nevertheless, for a small country servicing $\$ 98 \mathrm{~m}$ in loans was a considerable burden, and international lenders made their facilities dependent on a thirty year tolling contract with the aluminium smelter that guaranteed payments of $\$ 200 \mathrm{~m}$ for electricity over the lifetime of the contract. Thus through Valco the aluminium companies effectively

\footnotetext{
9 \$5.2bn in terms of the overall size of the US economy, see EH.net calculator: http://www.measuringworth.com/calculators/uscompare/ [accessed 28

September 2009].
} 
guaranteed that Ghana would possess the funds to service its debt, giving Kaisers enormous bargaining power with all sides. This kind of project fell clearly into the 'distributive arena of power' (Lowi, 1964), where individual firms could exert significant influence over distinct deals.

The aluminium smelter in turn was funded by a $\$ 96 \mathrm{~m}$ mortgage from the US Eximbank, $\$ 12 \mathrm{~m}$ stock subscription by Kaisers (ninety percent) and Reynolds (ten percent), amounting to a total of $\$ 108 \mathrm{~m}$. The remaining $\$ 20 \mathrm{~m}$ to construct the smelter were forwarded under a thirty year contract to use and pay for Valco's smelting service (total payments were to amount to $\$ 1 \mathrm{bn}$ over the lifespan of the contract). The Valco investment was dually protected through a US political risk guaranty (see III.1) and by a Master Agreement with the government of Ghana that fixed rates and provided freedom from expropriation.

The financial arrangements meant that Kaisers was in an unusual position vis-àvis the Ghanaian and US governments. Kaisers were providing the engineering for the dam, and their subsidiary Valco would be the major consumer of the power it produced. Hence Kaisers served as the consultants and advisors to Nkrumah, while also being the interested party (Hart, 1980). Valco itself was a tolling company getting alumina from its parent companies, and returning aluminium to them, making it completely dependent on its suppliers, which were also its customers, and owners.

\section{Figure 5: Volta River Project funding}




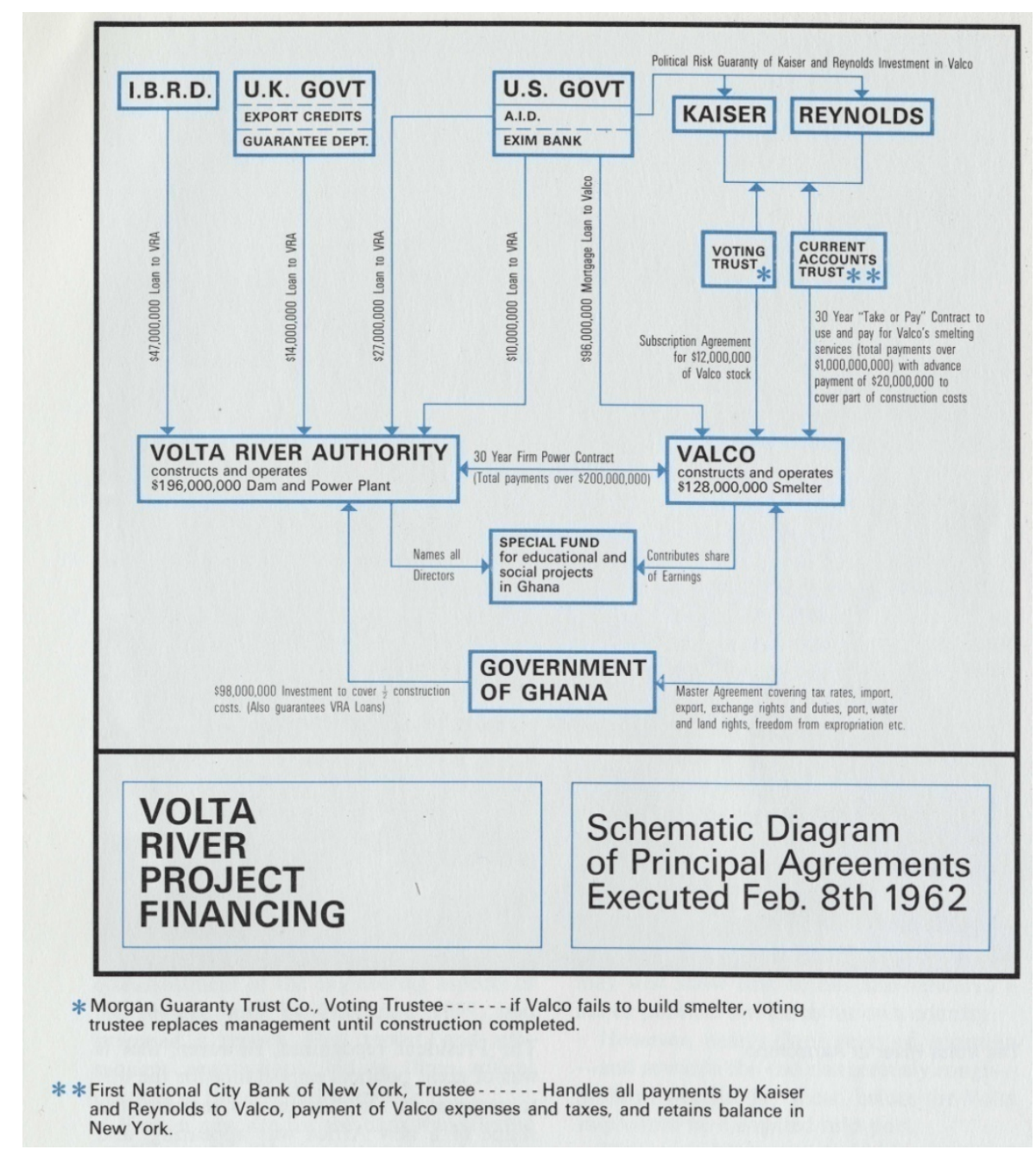

Source: "The Volta River Project", BANC MSS 85/61c, Ctn. 200 fl. 18.

\section{Il.4 Kwame Nkrumah's non-alignment policy}

Nkrumah's understanding of the Cold War differed fundamentally from that of the "West". Some of his letters indicate that he perceived himself in somewhat grandiose terms as an elder statesman trying to resolve the conflict in the Middle East. ${ }^{10}$

Nkrumah saw global superpower rivalry in the light of anti-colonialism. Kaisers appeared to have been capable of communicating on the basis of Nkrumah's anticolonialism as well as US Cold War rhetoric (Noer, 1984, pp. 65-68, 78). This allowed the company to occupy an important position in the diplomatic negotiations. US perceptions that Nkrumah was simply pro-Soviet were qualified by Kaiser intelligence from the Vice President Chad Calhoun. In February 1963 Nkrumah complained in a discussion of his non-aligned policy that both sides mistrusted him as a result:

10 Nkrumah to Lyndon B. Johnson, 15.4.64, PRAAD SC/BAA 309. 
“Calhoun: 'The Russians too?'

'Oh my', he exclaimed, 'they are the worst of all - they are always

complaining.' Then he added, 'They don't trust you unless you are a

Communist - so they don't trust me."'11

Although Ghana had gained Western support for the VRP and Russian investment for the smaller Bui hydroelectric dam - which never went ahead Nkrumah's non-aligned policy only served to bring Ghana into disrepute with both sides, something Nkrumah did not acknowledge claiming that "all his thoughts, actions and concern were in keeping the cold war out of Africa." 12 While Nkrumah's anti-colonialism was accepted to an extent by the US in the 1950s and early 1960s, this changed between 1962 and 1963. After Kennedy's assassination, the diplomatic relationship with the Lyndon B Johnson administration became quite antagonistic. Connelly's (2000) distinction between US concerns over a North-South conflict relative to the East-West conflict became obsolete, as anti-colonialism now came in only two flavours: pro-West or pro-Soviet (Westad, 2005, pp. 152-157).

Kaisers' close links with Nkrumah were mediated by a range of people: within the company Chad Calhoun served as main liaison. Edgar Kaiser also had close contacts with Sir Robert Jackson (Murphy, 2006, pp. 123-129) - and his wife Barbara Ward, who was not only friends with Nkrumah, but also with John F Kennedy. Chad Calhoun retired in July 1965.13 Robert Jackson and Barbara Ward continued to believe in the survival chances of their "wayward genius" despite the fact that most observers believed by early 1965 that Nkrumah's fate was sealed in the face of the political, economic and financial crises of the country. ${ }^{14}$ Edgar Kaiser travelled to Ghana for the Valco groundbreaking at Tema (see Figure 6), and the festive dedication of the Akosombo dam on 22 January 1966, about a month before the coup that deposed Nkrumah on 24 February 1966.

Figure 6: Kwame Nkrumah and Edgar F Kaiser hugging, 1965

${ }^{11}$ Calhoun to Kaiser, BANC MSS 87/35c, 21.2.63,Ctn. 41, fl. 10.

12 "Notes of a meeting at Accra, Ghana, between Kaiser, Calhoun with Nkrumah", 4-5.10.61, BANC MSS 87/35c , Ctn. 42 fl. 4.

${ }^{13}$ Kaiser to Nkrumah, 17.7.65, 85/61c, Ctn. 321, fl. $1 \mathrm{~g}$.

${ }^{14}$ Barbara Ward to Kaiser, 4.2.66, Ctn. 323, fl. 4c; Jackson to Calhoun, 31.3.65, 85/61c, Ctn. 321, fl. 1e. 


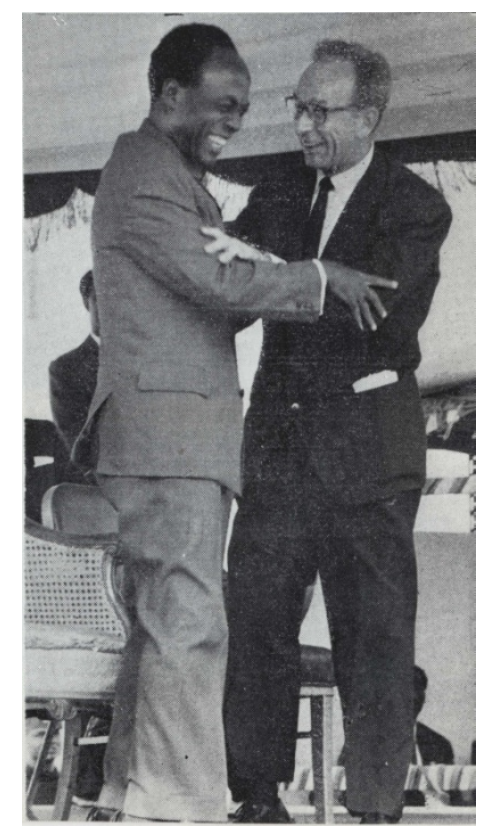

Source: VRA Magazine, Vol 1, No 1 (Feb 1965), BANC MSS 85/61c, Ctn. 321, fl. 1e.

\section{Kaisers and the VRP}

\section{III.1 Negotiating political risk insurance, 1961}

Kaisers had negotiated very favourable conditions for Valco. The smelter was exempt from income taxes in the first ten years of operation, in addition to certain other Ghanaian taxes for a thirty-year period, under the Pioneer Industries Act. On withdrawing from the aluminium consortium that originally constituted Valco, Olin Mathieson congratulated Edgar Kaiser on the finance arrangements and the "guaranty of the proposed investment against political risk."15 This guaranty from the US government had been agreed in March 1961, and was "far more than any hitherto ever considered by the Government."16

Kaisers perceived that the political imperative that had driven the VRP to the point of agreement in 1961, together with its high visibility, gave them an opportunity to negotiate better political risk guaranties. They held a unique position as the only aluminium company seriously committed to the project (Reynolds maintained a ten percent stake, but was effectively a silent partner), as the other consortium partners dropped out between December 1960 and July 1961. Without private enterprise willing to invest in the aluminium smelter, the World Bank would not release its loan as it insisted on a confirmed power consumer. ${ }^{17}$

Edgar Kaiser had already surprised the outgoing Eisenhower administration with his plea for extensive government guaranties to protect his company in case

15 Stanley, Olin Mathieson Chemical Corporation, to Edgar Kaiser, 20.7.61, BANC MSS 87/35c, Ctn. 42, fl. 4; VRA Magazine, Vol 1, No 1 (Feb 1965), BANC MSS 85/61c, Ctn. 321, fl. 1 e.

16 Calhoun to Kaiser, 13.3.61, BANC MSS 87/35c, Ctn. 42, fl.1.

17 GR Ward, memorandum, 2.2.61, BANC MSS 87/35c, Ctn. 41, fl. 39. 
of expropriation. His vice president Chad Calhoun then presented the project to the Kennedy government as a major battle in the Cold War in Africa. While his company was prepared to play their part in the economic cold war, he argued, they could not be expected to take the full risk, especially since it had been the government that had asked the aluminium companies to contribute to what was essentially a politically driven project. In 1959 the Eisenhower administration had told Kaisers that it would even finance the private smelter if necessary. By 1961, however, Kennedy indicated that Nkrumah's criticism of US policy in Africa jeopardised this commitment (Noer, 1985, pp. 65-68). ${ }^{18}$

The key issue was whether Nkrumah was a communist, or a socialist. A socialist, according to Kaisers, was acceptable - a company memorandum classified the UK, India and Israel as essentially socialist countries. ${ }^{19}$ Yet Kaisers did not want to downplay the political risk of the venture. As a result they found themselves on the one hand presenting Nkrumah's government as a high political risk for a private company, yet on the other hand they were advocating to the Kennedy government to go ahead with the VRP, as Nkrumah was a sincere and reliable partner (see section III.2).

In their negotiations, Kaisers argued that the standard FRIA type of political risk guaranty was not adequate as it did not cover political risks such as revolution, riots and civil strife, nor any US trade restrictions. Also the guaranty could not cover more than twenty years, when Kaisers was to sign a contract for thirty. Also the FRIA coverage of expropriation risks was vague, and described as "an invitation to a law suit." 20 The aluminium consortium preferred a DLF guaranty for ninety percent of their equity investment, assuming that ten percent would be normal business risk. This was not actually accurate, because Valco was a tolling company, and had no normal business-type risk (other than theft, accidents etc.). The government basically accepted this, with backing from Kennedy directly, and Kaisers were satisfied that the coverage was very near comprehensive. ${ }^{21}$

By October 1961, US-Ghanaian relations had gotten so strained as to endanger the VRP, and Edgar Kaiser met Kwame Nkrumah. Moxon's (1969, 1984, pp. 112113) account of this seems to downplay the intense antagonism and sense of crisis that is evident in the archival sources. In a lengthy meeting, Kaiser made it clear that although the company had political risk guaranty from the US, he was not willing to enter the deal if there was the slightest probability it would ever be used. ${ }^{22}$ Nevertheless, in December 1961, in a final diplomatic éclat with the US,

18 Lloyd N Cutler, Memorandum, 12.6.59, BANC MSS 85/61c, Ctn. 293, fl. 7d.

19 "Memorandum on the Economic, Industrial Development and Investment Climate of Ghana", 18.10.60, BANC MSS 87/35c, Ctn 41, fl. 38; "Notes of a meeting at Accra, Ghana, between Kaiser, Calhoun with Nkrumah", 4-5.10.61, BANC MSS, 87/35c, Ctn. 42, fl. 4.

20 Calhoun to Kaiser, 6.3.61, BANC MSS 87/35c, Ctn. 41, fl. 39.

${ }^{21}$ Ibid; "Memorandum: Valco Financing", 7.3.61; "Memorandum on Valco file", 8.3.61; Calhoun to Kaiser, 13.3.61; BANC MSS 87/35c, Ctn. 42, fl. 1.

22 Notes of a meeting at Accra, Ghana, between Kaiser, Calhoun with Nkrumah", 4-5.10.61, BANC MSS 87/35c, Ctn. 42, fl. 4. 
Nkrumah had prepared a speech indicating his future intention to take an ownership stake in Valco, and under threat that the VRP might still be abandoned by the US government, he changed this into an assurance that Ghana guarantied the smelter against expropriation for the first thirty years of operation (Noer, 1984, pp. 77-78). ${ }^{23}$ As a result, Valco was protected by multiple guaranties (and favourable tax legislation) that ensured that the company was treated much more advantageously than the rest of the foreign business community.

This unusually favourable treatment was clearly a response to several factors: in general, companies could gain greater individual influence and favourable treatment in the distributive 'arena of power'. Secondly, due to the antagonistic relationship between Ghana and the US, and Ghana's insecure investment environment, there were only few companies willing to take the risk.

\section{III.2 The VRP negotiations, 1961-1962}

Kaiser and his associates played a prominent role in the protracted VRP negotiations, reassuring Kennedy about Nkrumah's sincerity and reliability, while conveying to Nkrumah the need to moderate his political stance. Kaisers' ability to serve as diplomatic mediators between the US and the Ghanaian presidents showed that Edgar Kaiser, Chad Calhoun, Barbara Ward and Robert Jackson had some insight into the still undecided US Cold War doctrine for Africa, as well as the non-aligned agenda in newly decolonised Africa.

Barbara Ward had privately recommended to Kennedy to go ahead with the VRP in 1961. Walt Whitman Rostow, the president's official advisor on the matter, even jokingly remarked to Chad Calhoun that if both he and the Lady Jackson started telling Kennedy to go ahead, he would accuse them of being paid lobbyists. ${ }^{24} \mathrm{~A}$ few weeks later, Calhoun wrote Barbara Ward:

"[...] you might point out that as an aluminum project as such neither we nor the other companies are at all eager to get into this Ghana venture, but that Edgar and I have felt an over-riding responsibility and duty and that I have had to use oxygen, scotch tape and baling wire and bits of string to keep the whole thing going." 25

Although Edgar Kaiser had defended Nkrumah in the US since 1959, by the end of 1961 he had made it clear that he would not stand in the way if the Kennedy administration backed out of the project (Noer, 1984). Kennedy had in jest reminded Kaiser that if the Ghanaians "ever take over the plant and we have to make good on the guarantee, both you and I will have to leave the country."26

23 “Osagyefo's broadcast to the nation", 22.12.61, BANC MSS 83/42c, Ctn. 173, fl. 1.

${ }^{24}$ Rostow was the author of the highly influential The stages of economic growth (1960).

25 Chad F Calhoun, telegram [n.d., pres. between 10-13 Feb 1961], BANC MSS

87/35c, Ctn. 41 fl. 39; Chad Calhoun to Lady Barbara Jackson, 5.3.61, BANC MSS 87/35c, Ctn. 42, fl. 1.

${ }^{26}$ Memo: Meeting with Kennedy, 11.10.61, BANC MSS 87/35c, Ctn. 42, fl. 4. 
The high degree of visibility of Kaisers' involvement on this controversial issue, which was covered in a major article in Fortune magazine "Edgar Kaisers' gamble in Africa" (Siekman, 1961), made Kaisers vulnerable to failure.

Early in October 1961, when the whole project was in jeopardy because of Nkrumah's increasingly pro-Soviet statements, Edgar Kaiser and Chad Calhoun were dispatched to speak to the Ghanaian president. In two lengthy meetings with Nkrumah, Edgar Kaiser bluntly informed him of the poor impression of Ghana abroad, and how his behaviour endangered the commitment of KACC and Reynolds to the aluminium company. Nkrumah argued that "any position he took was not in relation to the desires of either the East or the West, but was in the context of what he thought was best for Ghana, Africa, disarmament, and world peace."27 The businessmen found Nkrumah disturbed that Kennedy was questioning his motives and that he was not perceived abroad as a neutral like Nehru. In response to Edgar Kaiser's insistent questioning of why he let the Russians built the hydroelectric dam at Bui, Nkrumah even admitted that this had been a mistake, but did not agree to letting Kaiser look for alternative sources of finance. Kaiser and Calhoun, after years of negotiations and arrangements for the VRP, ignored this indication that Nkrumah was intent on gaining Soviet investment in addition to US capital, and that he did not feel tied to the West as a result of the VRP.

Nkrumah clearly did not consider that the Manichean worldview of the Cold Warriors would be applied to his international policies:

"Mr Kaiser told Nkrumah that there were constant reports the people now closest to him were communist.

"Sheer balderdash, complete balderdash," he exclaimed quite heatedly.

"The trouble is," he said, " that too many people confuse nationalism with Communism."

"And," he continued, "we are African and for Africa and trying to work out a socialist form of government adapted to our particular needs." And then, he repeated, "Nationalism should not be confused with Communism."'28

In response to this meeting, Nkrumah immediately despatched a letter to Kennedy, and Calhoun met with the US president shortly after he returned from Ghana. A day before this meeting Calhoun received a report from Barbara Ward, who felt she had made progress in convincing Kennedy that even other friendly African countries critical of Nkrumah would consider the US withdrawal as a slap in the face and that the Ghanaian president was truly non-aligned in his policies, a position reiterated by Senegal's president Leopold Senghor in November. For Kennedy, it was not necessarily the reception in Ghana that mattered, but the battle for the hearts and minds of many new African nations. In this, his concerns were more similar to those of the Eisenhower administration (Connelly, 2000) than hitherto noted. Kennedy's desire for a diplomatic rapprochement with Ghana in order to avoid alienating newly independent

27 Calhoun to Kaiser, 10.10.61, BANC MSS 87/35c, Ctn. 42, fl. 4.

${ }^{28}$ Calhoun to Kaiser, 10.10.61, BANC MSS 87/35c, Ctn. 42, fl. 4. 
countries in Africa and elsewhere opened up significant and unique opportunities for a politically astute firm like Kaisers.

On 11 October 1961 in their meeting with Kennedy, Kaiser and Calhoun clearly stated that they believed that he would keep his word, especially not to forcibly expropriate Valco. Kennedy was particularly concerned that too much aid money was spent on a questionable regime instead of 'deserving' African countries. Kaiser pointed out that only $\$ 27 \mathrm{~m}$ was loaned to Ghana, the rest were commercial loans from the Eximbank and the World Bank. This was new to Kennedy, and received with relief. Edgar Kaiser also strongly opposed pressuring Nkrumah to agree to US political conditions, and asked to be allowed to convince him first. ${ }^{29}$

On 18 October, Edgar Kaiser and Chad Calhoun were back in Ghana, meeting with Nkrumah and Barbara Ward. ${ }^{30}$ Shortly after, Nkrumah made an effort to demonstrate his neutralism, and by December Kennedy publicly announced that the US would support the VRP. Yet Nkrumah committed yet another diplomatic faux-pas by suggesting Ghana might like to gain participation in Valco in the future (Noer, 1984, pp. 77-78), leading to another intervention by exasperated US politicians before the VRP agreements were finally signed in January 1962.

What was Kaisers' influence on the negotiations of the VRP? By leveraging the influence of Robert Jackson on Nkrumah and his wife Barbara Ward on Kennedy, Edgar Kaiser and his vice president, Chad Calhoun, had important allies right at the heart of presidential decision-making in 1961. The access Calhoun and Kaiser themselves enjoyed to both presidents in October 1961 was also significant. Kennedy commented in their meeting that Kaiser had been presented to him as "the greatest industrial statesman that ever existed."31

Kaisers' role in the success of the VRP negotiations would ensure Kaisers' continued influence in Ghana. In the US, however, the project was highly controversial, and Kaiser was criticised for their visible influence on the political process. In 1964, Kaisers was attacked for its role in the VRP by Senator Albert Gore as "having sold the government a bill of goods, it all had to do with Barbara Ward though he doesn't know how."32

Kaisers' influence in Washington as government entrepreneur was significant for the eventual US backing of the VRP, as it was a highly political decision and followed from the still emerging logic of US Cold War policy (Connelly, 2000; Westad, 2005). Yet this high visibility made Kaisers vulnerable later: the project could not be allowed to fail, for political and commercial reasons.

\footnotetext{
${ }^{29}$ Memo: Meeting with Kennedy, 11.10.61, BANC MSS 87/35c, Ctn. 42, fl. 4.

${ }^{30}$ Calhoun, "Notes of meeting at Accra, 18. and 19.10.61", 23.10.61, BANC MSS

87/35c, Ctn. 42, fl.4.

31 Memo: Meeting with Kennedy, 11.10.61, BANC MSS 87/35c, Ctn. 42, fl. 4.

32 Richard L Spees to RE Knight memo 7.4.64, BANC MSS 85/61c, Ctn. 320, fl. 6b.
} 


\section{III.3 The Capital Investment Bill, 1962-63}

In how far did Kaisers' relationship with Nkrumah allow them to influence presidential decisions in Ghana, especially with regard to economic policy? What were the limits of their influence on Nkrumah? How far did Kaisers try to exploit their influence with Nkrumah? The time period between 1963 and 1964, from the drafting of the Capital Investment Bill to the publication of the Seven-Year Development Plan, provides some answers to the above questions.

The Capital Investment Bill was published in April 1963, but Kaisers' management had become concerned with some of the early suggestions made in October 1962, especially the compulsory reinvestment of sixty percent of profits, which might put the company under pressure to surrender some favourable positions of the Master Agreement. ${ }^{33}$

Allan Sprout, former president of the Federal Reserve Bank of New York, even wrote Edgar Kaiser in December 1962 that he had been handed a "hot potato in this Ghana business. I have begun to think the excesses of a dictatorship, or assassination, or revolution, will soon so alter the situation there, regardless of temporary accommodation [sic] with Nkrumah, as to make it necessary for the US to re-examine [sic] its whole position." 34 This comment highlighted the deteriorating diplomatic relationship with the US, but did not dissuade Kaisers from further involvement.

While Edgar Kaiser's relationship with Nkrumah has been the focus of attention, it appears that Chad Calhoun's friendship with Nkrumah was more significant. His entire correspondence with Nkrumah was vetted by Edgar Kaiser and the White House (as were Edgar Kaiser's). In February 1963, Kaiser sent Chad Calhoun "to see if he can get an investment bill adopted by Ghana that will provide an attractive climate for private investment." 35 However, RE Knight, the managing director of Valco, cautioned his boss:

"I feel that Chad's relationship with Nkrumah is a unique and valuable asset. [...] My concern is that this entails certain inherent risks to our relationships, both in Ghana and in our own Government, but principally in Ghana."36

From the correspondence between Calhoun and Kaiser, it becomes clear that Calhoun debated all aspects of the bill with Nkrumah, that his work on the drafting went into the precise phrasing of the document, and that he carefully, and apparently successfully, sought to eliminate dissenting voices. ${ }^{37}$

\footnotetext{
33 RE Knight to Chad F Calhoun, 16.10.62, BANC MSS 87/35c, Ctn. 42, fl. 9

${ }^{34}$ Allan Sprout to Edgar F Kaiser, 21.12.62, BANC MSS 85/61c, Ctn. 318, fl. 5 a.

35 Nkrumah considered an unvetted newsclipping send by Calhoun as evidence that the US was trying to "meddle in internal affairs." Kaiser to George D Woods, 7.2.63, BANC MSS 87/35c, Ctn. 42, fl 10.

${ }^{36}$ Knight to Kaiser, 26.10.62, BANC MSS, Edgar 85/61c papers, Ctn. 321, fl. 1 l.

37 Calhoun to Kaiser, 3.3.63, Calhoun to Kaiser, 4.3.63, BANC MSS 85/61c, Ctn. 318, fl. 5c.
} 
It seemed that Calhoun's involvement paid off, with extremely generous conditions for projects approved under the new bill:

- The 1962 decree requiring reinvestment of 60 percent of annual net profits would not apply, but the general 10 percent compulsory savings levy would.

- Five year property tax exemption

- Five to ten year income tax exemption

- Special depreciation allowance of 40 percent in the first year and 20 in subsequent year

- Exemption from import duties and purchase taxes for export industries using local materials

- Waiver of tax on dividends to non-residents. ${ }^{38}$

After this textbook example of corporate political power, by October 1963 it became apparent that Kaisers and the rest of the business community had been misled.

\section{III.4 The revision of income tax legislation, 1963-64}

In October 1963 changes in tax legislation were announced, which "neutralised the good effect of the Capital Investment Law."39 It was, however, not the increases in company taxation that caused concern, which rose from 40 percent plus five percent on earnings not retained in Ghana, to 45 and 25 percent respectively. Personal income tax more than doubled, in the lower bracket from 15 to 32.5 percent, and incomes over $£ 7,200(\$ 20,200)$ increased from 33 to 70 percent. Through this measure the receipts from personal income tax would double to $£ 3$ million. It also had the side effect of making expatriate employment in Ghana singularly unattractive. ${ }^{40}$ While previous negotiations had broadly fallen into what Lowi (1964, pp. 692-715) called the 'distributive arena', taxation was clearly a redistributive issue, usually dominated by collective business action through peak associations with a strong ideological agenda. Here Kaisers' strategy showed remarkable weakness.

The British business community, especially the Unilever-United Africa Group and Major-General Spears of Ashanti Goldfields Ltd. were aware that Kaiser had unique access to Nkrumah. Frederick Pedler of the United Africa Company sought contact to Kaiser through Calhoun in August 1963, before the change in income tax. In January 1964, Calhoun met with Pedler, Arthur Smith, and Arthur Anderson of the Unilever-United Africa Group. They hoped that Nkrumah could "be guided on a fairly permanent, more rational course. They feel that only we - -

${ }^{38}$ Business International, 19.4 .63 , pp. 4-5. These exceptionally generous conditions led to objections from Nicholas Kaldor, Nkrumah's economic advisor (the successor of W. Arthur Lewis, the Nobel laureate), which only delayed the president's signature. RE Knight to Kaiser, 7.5.63, BANC MSS 85/61c, Ctn. 318, fl. $5 c$.

${ }^{39}$ Knight to Kaiser, 30.10.63, BANC MSS 85/61c, Ctn. 318, fl. 5 f.

40 Robert L Bridges to Kaiser, 20.4.64, BANC MSS 87/35c, Ctn. 42, fl. 13. 
Kaisers - - can do it", concluded Calhoun. ${ }^{41}$ Calhoun was inclined to agree with the British businessmen:

"I think that if we, the US, the West, and we personally, are smart enough, adept enough and act promptly, he [Nkrumah] can be pulled back along a more rational and stable course." 42

As it turned out in July 1964, Unilever was mainly interested in a closer relationship with Kaiser in order to find an ally on the income tax problem, or at least get Kaisers to disclose the deal the company had recently agreed with the Ghanaian government with regard to the income tax on their employees. The details of Kaisers' arrangement are not in the files, but as Knight reiterated in a letter to Calhoun, advising him on his dealings with Pedler, the solution was for Valco only, and meant to be treated confidentially, placing a "moral obligation" on Kaisers not to disclose it. ${ }^{43}$

Other British business representatives also approached Edgar Kaiser in February to use his influence on Nkrumah, which Kaiser rejected:

"We do not think we should become involved in the political affairs of Ghana. We fully recognize that the latter may affect our business responsibilities." 44

This is ironic considering Kaisers' political activities during the negotiations for the VRP and the drafting of the Capital Investment Act. Moxon (1984, p. 207-8, 270) argued that from 1963 Kaiser began to have doubts about Nkrumah's direction as a result of the anti-American protests in Ghana. From 1964 onwards it seems that Edgar Kaiser had also become wary of his company's visibility in Ghana. As a result, Kaiser set down a policy for their business in Ghana:

"I think we should keep out of the politics and certainly should not become involved in grinding axes for the British or anyone else. Naturally, if our Government asks us to do something, we will give it careful consideration, but we should not under any circumstances get ourselves in the position of suggesting that we can influence Nkrumah one way or another. This could easily be interpreted by Nkrumah as a move on our part for some, as he puts it, imperialistic or other reasons. Let us confine ourselves to doing our business under our arrangement the very best we can, with full integrity, which has always merited his confidence." 45

Hence February 1964 marked a stark departure from Kaiser's position during the VRP negotiations, when he had positively insisted on using his influence with

\footnotetext{
41 Jackson to Calhoun, 8.8.63; Calhoun to Kaiser, 19.12.63, Ctn. 42, fl. 11; Calhoun, "Comments, observations, events and miscellaneous information", January 1964, BANC MSS 87/35c, Ctn. 42, fl. 12.

42 Calhoun to Kaiser, January 1964, BANC MSS 85/61c, Ctn. 320, fl. 6a.

${ }^{43}$ Knight to Calhoun, BANC MSS 87/35c, Ctn. 42, fl. 13.

${ }^{44}$ Kaiser to Sir John Howard, 6.2.64; Howard to Kaiser, 31.1.64, BANC MSS

85/61c, Ctn. 320, fl. 6b.

${ }^{45}$ Kaiser to Calhoun, 4.2.64, BANC MSS 85/61c, Ctn. 320, fl. 6b.
} 
Nkrumah. ${ }^{46}$ Clearly Kaisers' position in Ghana was affected by the momentous political events in the USA, where Kennedy was assassinated on 22 November 1963, and Lyndon B Johnson was sworn in as the new president, and subsequently elected in November 1964. With Johnson came a new concern about the involvement of the CIA in Ghana, which gained support from a file declassification in 1999. 4748

According to Moxon (1969, 1984, p. 270), Kaiser was informed from more than one direction that Nkrumah would be deposed before the smelter would be completed. Previous intelligence, such as from the State Departments in 1961, or Alan Trout's letter from 1962, was disregarded. ${ }^{49}$ Only from February 1964 onwards, Edgar Kaiser clearly decreed a shift in corporate political activities in Ghana towards less involvement and visibility that starkly contrasted with the company's previous strategy. In July 1964, Calhoun was approached by Albert Coleman of Eastern Affiliates, the downtown front for the CIA in Ghana, to provide intelligence, which he rejected. Kaisers' top management now reviewed any letters to Nkrumah even more carefully where political issues were concerned, such as the World Bank, so that these could not be construed as meaning that Kaisers held political influence. ${ }^{50}$ Thus, although there is no direct evidence that Kaisers had received a warning from the CIA, it is likely that this would not have been put to paper. The timing suggests some political intelligence.

Yet Edgar Kaiser was uneasy with the defensive position he had taken, especially in relation to the wider foreign business community in Ghana. He expressed his concern in a letter to Calhoun in January 1964, worrying about how Valco could be successful when it was the only private venture with very special tax and other concessions. He reiterated that these were necessary to arrange the financing, but he hoped that Nkrumah would understand that it was not fair to penalize expatriates with taxes. ${ }^{51} \mathrm{He}$ also wrote $W$ Averill Harriman, the Undersecretary of State for Political Affairs, pointing out that there were few

46 Calhoun, "Meeting with Kennedy", 11.10.61, BANC MSS 87/35c, Ctn. 42, fl. 4.

47 Paul Lee, "Documents Expose U.S. Role in Nkrumah Overthrow",

SeeingBlack.com, 7.6.02

[http://www.seeingblack.com/x060702/nkrumah.shtml, accessed 19.1.10]. This website contains a link to archival files released by the State Department at http://www.state.gov/www/about_state/history/vol_xxiv/s.html.

48 Nkrumah to Lyndon B. Johnson, 26.2.64, PRAAD SC/BAA 309. The fears

Nkrumah expressed in this letter have been widely accepted as fact in Africa, see George Sydney Abugri, "The president who was bombed again and again", New African 490 (December 2009), pp. 40-41.

49 "Notes of meeting at Accra, Ghana, 4-5 Oct 1961 between Kaiser, Calhoun with Nkrumah", BANC MSS 87/35c , Ctn. 42, fl. 4; Jackson to Edgar, 28.12.64, 85/61c papers, Ctn. 321, fl. 1e.

50 Calhoun to Kaiser, 30.7.64, fl. 1a; RE Knight, Note dated 23.11.64, on a draft letter Calhoun to Nkrumah, fl. 1m; all BANC MSS 85/61c, Ctn. 321.

51 Kaiser to Calhoun, 9.1.64, BANC MSS 85/61c, Ctn. 320, fl. 6 a. 
investments other than Valco and the British, and that Valco's incentives such as taxes should be available to others. ${ }^{52}$

In November 1964 Nkrumah approached Kaisers for an industrial survey, which Edgar surprisingly declined - his company carried out twenty-one consultancies between 1959 and 1974 (Moxon, 1969, 1984, p. 268) - and suggested to contact George Woods of the World Bank. This came as the result of advice from his legal counsel, Lloyd N Cutler:

"Since Nkrumah will probably not take our economic advice anyway, we will only involve ourselves needlessly by giving it. If we become intimate participants in the economic planning of Nkrumah's Government and a violent upheaval against him should then occur, the next Government might equate us with Nkrumah's Cabinet and his other political supporters, and charge us with all sorts of crimes against the state."53

Cutler's statement could have been based on confidential information, but equally on a careful observation of the political and economic situation in Ghana. The high visibility of the VRP, and Kaisers, both in Ghana and abroad, meant that Kaisers was now concerned that it may render them a target for politically motivated expropriation. The relationship to subsequent Ghanaian governments was never again quite as close, which can be attributed to two factors. ${ }^{54}$ Firstly, diplomatic conditions had changed, and for the US the East-West conflict had gained supremacy over any anti-imperialist concerns (Connelly, 2000). As a result, Valco's visibility was now more of a potential liability than previously still a highly effective "calling card" for hydro projects in West Africa and elsewhere, but also a target of veiled accusations in the Ghanaian press. ${ }^{55}$

\section{Conclusion}

Nkrumah was overthrown shortly after the dedication of the dam. Kaisers continued to run the smelter until 2004, when they sold the nearly obsolete plant to a democratic Ghanaian government that did not produce aluminium in the face of the increasing domestic demand for electricity and shortages in production. Although Kaisers' influence in Ghana never again rivalled its early peak under Nkrumah, the company retained significant bargaining power through Valco and the Master Agreements, which governed the relationship to the government and the power authority. Thus Kaisers' influence on the political

\footnotetext{
52 Kaiser to Harriman, 12.5.64, BANC MSS 87/35c, Ctn. 42, fl. 13.

53 Lloyd N Cutler, Memorandum for Mr. Edgar F Kaiser - Subject: Ghana Industrial Survey, 27.11.64, BANC MSS 85/61c, Ctn. 321, fl. 1c.

${ }^{54}$ Robert Jackson to Edgar Kaiser, 14.12.72, BANC MSS 85/61c , Ctn. 341.

55 Ward B Saunders to Kaisers, 2.11.72, Ctn. 331, fl. 2v; Calhoun to Kaiser, 24.11.64, referring to Ghanaian Times front page of 18.11.64, Ctn. 321, fl. 1b; all BANC MSS 85/61c.
} 
and economic environment in the early 1960s had long-term implications for the host economy.

Clearly Kaisers was unusually influential in Nkrumah's Ghana, but the company's importance was based on factors such as visibility and information asymmetry. Kaisers' influence in Washington boosted their relevance in the Ghanaian context, and their high visibility ensured political protection and favourable treatment. Their influence in Washington, even as a 'government entrepreneur', was dependent on their ability to explain and mediate the relationship to Nkrumah, and to act as an informal go-between when official relationships were strained. Yet once the general attitude in the US changed, Kaisers' influence declined, although they still had the protection that their high visibility afforded them. Their tactics in Ghana, however, became significantly more cautious and defensive, and the release of new taxation legislation, to which they were not privy in advance (in contrast to Chad Calhoun's involvement in the drafting of the Companies' Decree), marked their increased distance from the decisionmaking process (even though they could negotiate a separate and favourable settlement on the basis of the Master Agreements).

Kaisers showed a dynamic response to opportunities created by international and domestic policies that was largely independent of the level of political risk in the host economy (see also Haber, Maurer \& Razo 2003). This level of risk could be managed by an individual company with the right networks and the right political skills, but depended on sensitive awareness of dynamic political factors. Interestingly, these opportunities and threats were largely independent of the high-risk host environment, which is what most models of corporate political activities focus on. High visibility can be both an asset and a curse for a firm in high political risk situations, and requires careful management. Hence only companies with location-specific political capabilities exploit these opportunities, which explain why there are some high profile companies who successfully invest in high-risk countries, but also on occasion fall foul if they do not carefully manage their high visibility - for example the TNK-BP joint venture in Russia, or the oil companies, such as Exxon-Mobil, involved in the ChadCameroon Oil Pipeline project.

The political activities of multinationals need to encompass two locations, home as well as host economy, to be effective. Kaisers is an interesting case, because it achieved higher levels of influence than existing explanations would lead us to expect. Kwame Nkrumah's hostility to foreign investment and 'neo-colonialism' in all forms did actually enable Kaisers' use of dynamic factors such as corporate diplomacy. Thus political risk, normally considered to limit corporate influence, augmented it as a result of Kaisers' strategy. Kaisers was similarly very successful in achieving its goals in the US, more so than the existing categorisation of the country as a pluralistic, liberal market economy suggests. Hence future research could benefit from focusing on strategic opportunities created by dynamic conditions in the political and economic environment of investors. 


\section{Bibliography}

Adams, S. B. (1997). Mr. Kaiser Goes to Washington: The Rise of a Government Entrepreneur. Chapel Hill: University of North Carolina Press.

Austin, G., \& Uche, C. U. (2007). Collusion and Competition in Colonial Economies: Banking in British West Africa, 1916-1960. Business History Review, 81(1), 1-26.

Bates, R. H. (1981). Markets and States in Tropical Africa: The Political Basis of Agricultural Policies. Berkeley, Los Angeles, London: University of California Press.

Bayart, J.-F. (1993). The state in Africa: the politics of the belly. London: Longman.

Bernhagen, P., \& Bräuninger, T. (2005). Structural power and public policy: A signaling model of business lobbying in democratic capitalism. Political Studies, 53(1), 43-64.

Bucheli, M. (2008). Multinational corporations, totalitarian regimes and economic nationalism: United Fruit Company in Central America, 1899,Äì1975. Business History, 50(4), 433 - 454.

Bucheli, M. (2010). Canadian Multinational Corporations and Economic Nationalism: The Case of Imperial Oil Limited in Alberta (Canada) and Colombia, 1899-1938. Entreprises et Histoire, 54(April), 67-85.

Chabal, P., \& Daloz, J.-P. (1999). Africa Works: Disorder as Political Instrument. Oxford: James Currey.

Connelly, M. (2000). Taking Off the Cold War Lens: Visions of North-South Conflict during the Algerian War for Independence. The American Historical Review, 105(3), 739-769.

Decker, S. (2010). Postcolonial Transitions in Africa: Decolonization in West Africa and present day South Africa. Journal of Management Studies, 47(5), 791-813.

Dicken, P. (2007). Global Shift: Mapping the Changing Contours of the World Economy (5th ed.). London i.a.: Sage.

Esseks, J. D. (1971). Political Independence and Economic Decolonization: The Case of Ghana under Nkrumah. The Western Political Quarterly, 24(1), 5964.

Evans, P. B. (1979). Dependent development: the alliance of multinational, state, and local capital in Brazil. Princeton (N.J.): Princeton University Press.

Gereffi, G., \& Evans, P. (1981). Transnational Corporations, Dependent Development, and State Policy in the Semiperiphery: A Comparison of Brazil and Mexico. Latin American Research Review, 16(3), 31-64.

Gould, J. A., \& Winters, M. S. (2007). An Obsolescing Bargain in Chad: Shifts in Leverage between the Government and the World Bank. Business and Politics, 9(2), 1-34.

Graham, R. (1982). The Aluminium Industry and the Third World: Multinational Corporations and Underdevelopment. London: Zed Press.

Guillen, M. F. (2000). Business groups in emerging economies: A resource-based view. Academy of Management Journal, 43(3), 362-380.

Haber, S., Maurer, N., \& Razo, A. (2003). When the Law Does Not Matter: The Rise and Decline of the Mexican Oil Industry. The Journal of Economic History, 63(1), 1-32.

Hart, D. (1980). The Volta River Project. A Case Study in Politics and Technology. Edinburgh: Edinburgh University Press. 
Hillman, A. J., \& Hitt, M. A. (1999). Corporate political strategy formulation: A model of approach, participation, and strategy decisions. Academy of Management Review, 24(4), 825-842.

Hillman, A. J., \& Wan, W. P. (2005). The determinants of MNE subsidiaries' political strategies: Evidence of institutional duality. Journal of International Business Studies, 36(3), 322-340.

Hove, J. O. (forthcoming). The Volta River Project and Decolonisation, 19451957: The rise and fall of an integrated aluminium project. In Bauxite, State and Society.

Jones, G., \& Amatori, F. (Eds.). (2003). Business History Around the World. Cambridge: Cambridge University Press.

Jones, T. (1976). Ghana's first Republic, 1960-1966: the pursuit of the political kingdom. London: Methuen.

Kaiser Corporation. (1968). The Kaiser Story. Oakland CA: Kaiser Industries Corporation.

Killick, T. (1978). Development economics in action: a study of economic policies in Ghana. London i.a.: Heinemann Educational.

Lenway, S. A., \& Murtha, T. P. (1994). The State as Strategist in InternationalBusiness Research. Journal of International Business Studies, 25(3), 513535.

Lowi, T. J. (1964). Review: American Business, Public Policy, Case-Studies, and Political Theory. World Politics, 16(4), 677-715.

Mager, A. K. (2008). Apartheid and business: Competition, monopoly and the growth of the malted beer industry in South Africa. Business History, 50(3), $272-290$.

Maltby, J., \& Tsamenyi, M. (2010). Narrative accounting disclosure: Its role in the gold mining industry on the Gold Coast 1900-1949. Critical Perspectives on Accounting, 21(5), 390-401.

Mayo, A. J., Enson, M. B., \& Chen, D. (2008). Henry J Kaiser and the Art of the Possible. Boston: Harvard Business School.

Moxon, J. (1969, 1984). Volta: man's greatest lake. New York: Praeger.

Murphy, C. N. (2006). The United Nations Development Programme. Cambridge: Cambridge University Press.

Murtha, T. P., \& Lenway, S. A. (1994). Country Capabilities and the Strategic State - How National Political-Institutions affect multiantaion-corporations strategies. Strategic Management Journal, 15, 113-129.

Noer, T. J. (1984). The New Frontier and African Neutralism - Kennedy, Nkrumah, and the Volta River Project. Diplomatic History, 8(1), 61-79.

Noer, T. J. (1985). JFK - Ordeal in Africa - Mahoney,RD. American Historical Review, 90(1), 242-243.

Peng, M. W. (2003). Institutional Transitions and Strategic Choices. Academy of Management Review, 28(2), 275-296.

Penrose, E. (1959). Profit Sharing between Producing Countries and Oil Companies in the Middle East. The Economic Journal, 69(274), 238-254.

Perchard, A. (2008). A marriage of mutual convenience? The British government and the UK aluminium industry in the twentieth century. Paper presented at the European Business History Association.

Perchard, A. (2010). 'Of the highest Imperial importance': British strategic priorities and the political economy of bauxite, c.1916-c.1958. In R. 
Gendron, M. Ingulstad \& E. Storli (Eds.), The Global Economic History of Bauxite. Vancouver: University of British Columbia Press.

Piquet, C. (2004 ). The Suez Company's Concession in Egypt, 1854-1956: Modern Infrastructure and Local Economic Development. Enterprise \& Society: The International Journal of Business History, 5(1), 107-127.

Rodney, W. (1972). How Europe underdeveloped Africa. London: BogleL'Ouverture Publications.

Rood, L. L. (1976). Nationalisation and Indigenisation in Africa. The Journal of Modern African Studies, 14(03), 427-447.

Siekman, P. (1961). Mr Kaiser's Gamble. Fortune.

Smith, J. S. (2006). Building New Deal Liberalism. Cambridge: Cambridge University Press.

Soskice, D., \& Hall, P. A. (2001). Varieties of capitalism: the institutional foundations of comparative advantage: Oxford: Oxford University Press.

Stein, M. (1980). A Special Difference: A History of Kaiser Aluminum \& Chemicals Company. Oakland, CA: Kaiser Aluminum \& Chemicals Company.

The Economist. (1956, 28 July 1956). The World Overseas: Pause on the Volta River. The Economist, pp. 323-324.

Tignor, R. L. (2007). The business firm in Africa. Business History Review, 81(1), 87-110.

Verhoef, G. (2008). Nationalism, social capital and economic empowerment: SANLAM and the economic upliftment of the Afrikaner people, 1918,Äì1960. Business History, 50(6), 695 - 713.

Vernon, R. (1973). Sovereignty at bay: the multinational spread of US enterprises. Harmondsworth: Penguin.

Westad, O. A. (2005). The Global Cold War. Cambridge: Cambridge University Press.

Widstrand, C. G. (Ed.). (1975). Multinational firms in Africa. Dakar: African Institution for Economic Development and Planning.

Wilson, E. J. (1990). Strategies of State Control of the Economy: Nationalization and Inidgenization in Africa. Comparative Politics, 22(4), 401-419. 